This is the peer reviewed version of the following article: Eiser D \& King D Allocating Grant to the UK's Devolved Territories by Needs Assessment: Lessons from School Funding Formulae in England and Scotland (2017), Fiscal Studies, 38: 81-109 which has been published in final form at https:// doi.org/10.1111/1475-5890.12088. This article may be used for non-commercial purposes in accordance With Wiley Terms and Conditions for self-archiving. 


\title{
Allocating grant to the UK's devolved territories by needs assessment: lessons from school funding formulae in England and Scotland
}

\author{
David Eiser (University of Stirling) \\ David King (University of Stirling)
}

\begin{abstract}
The UK's devolved administrations (DGs) receive block grants to finance almost all their expenditure. The Barnett formula used to calculate these grants is often criticised because it does not consider the DGs' spending needs. However, the feasibility of allocating block grants by needs assessment is often questioned, given the contestability of spending needs.
\end{abstract}

This paper compares the formula used within England to assess the education spending needs of local authorities there with the equivalent Scottish formula, by using each formula in turn to calculate the relative spending needs of the UK territories. The rationale is to consider how similar the two formulae are in how they estimate the territories' relative spending needs for education, a major responsibility of the devolved governments.

The results show that the English and Scottish education allocation formulae produce similar estimates of the territories' relative education spending needs. This suggests that it may be more feasible to allocate education resources to the UK's devolved territories based on needs assessment than some have suggested. The results also suggest some inequity in current patterns of education spending across the UK.

\section{Introduction}

Recent decades have witnessed increased decentralisation of public sector activity in many developed and developing countries (Lago-Peñas, et al., 2011). Consequently, a growing proportion

This article has been accepted for publication in Fiscal Studies and undergone full peer review but has not yet been through the copyediting, typesetting, pagination and proofreading process, which may lead to differences between this version and the Version of Record. Please cite this article as an 'Accepted Article', doi: 10.1111/1475-5890.12088

This article is protected by copyright. All rights reserved. 
of government revenues are used to finance subcentral levels of government. Across OECD countries around a quarter of central Government tax revenue is spent on inter-governmental grants (Blöchliger and King, 2006), and the question of how such grants are allocated is receiving widespread attention. Many countries utilise funding formulae for allocating grant to decentralised levels of government, but these formula differ widely. Australia for example uses an extremely detailed formula to allocate grant to States based on spending needs and tax capacity (Commonwealth Grants Commission, 2010); Spain uses a much simpler formula to allocate grant to Autonomous Communities based on spending needs (Bosch, 2009); whilst Canada allocates grant to Provinces based wholly on tax capacity, with no consideration of spending need (Lecours and Béland, 2010).

The three devolved governments (DGs) of the UK (the Scottish Government, the Welsh Government, and the Northern Ireland Assembly) currently have little ability to raise tax and are almost wholly reliant on a block grant from the UK government to fund their spending (although this is beginning to change, as discussed below). Since 1979 , these block grants (or more precisely, the annual changes in them) have been determined by the Barnett Formula. This formula determines the change to each DG's grant based on changes in spending on devolved services in England, and the DA's population (HM Treasury, 2010). For example, if the UK government announces a $f 100 m$ increase in health spending in England, if 99\% of all UK health spending is devolved, and if Scotland's population is $10 \%$ of England's, then the Scottish Government's budget would increase by $f 9.9$ million. Any Barnett-calculated change is added to the existing grant (the baseline). It follows that each territory's current grant level is a function of the grant that the territory received in 1979, and all subsequent applications of the Barnett formula.

The Barnett formula was introduced on the assumption that it would be a temporary measure, and has frequently been criticised as inequitable because it takes no account of the spending needs of the DGs and England (McLean, et al., 2008; Select Committee on the Barnett Formula, 2009; Independent Commission on Funding and Finance for Wales, 2010). The grant allocations have often been accused of being too generous to Scotland and Northern Ireland (NI), but less so to Wales (McLean and McMillan, 2005; Mackay and Williams, 2005). Although the Barnett Formula bears the brunt of this criticism, the formula cannot be blamed for creating any excess generosity: it can only be blamed for not sufficiently reducing any excess generosity that already existed in $1979^{1}$.

\footnotetext{
${ }^{1}$ A mathematical property of the Barnett Formula is that it should induce convergence in per capita spending levels between the devolved territories and England over time. This is because, for a given nominal increase in
} 
Recent years have seen growing calls for the Barnett formula to be replaced with a formula which takes some account of the territories' spending needs. The Holtham Commission (Independent Commission on Funding and Finance for Wales, 2010), the House of Lords Select Committee on the Barnett Formula (2009), the Commission on Devolution in Wales (2012), the Local Government Association in England (Local Government Association, 2013) and the All Party Parliamentary Taxation Group (2013) have all recommended that the formula should be replaced by a needs based spending assessment.

Greater autonomy over tax-raising is likely to be devolved to each of the DGs over the next few years, especially in Scotland. The Smith Commission, established following the 'no'-vote at the independence referendum in 2014, has recommended that control over income tax, half of VAT revenues raised in Scotland, and various other smaller taxes, should be devolved to the Scottish Government. These recommendations have already been written into draft legislative clauses (Cabinet Office, 2015) and are expected to be legislated for in the next parliament. The Wales Act devolves Landfill Tax and Stamp Duty tax to the Welsh Government, and income tax is expected to be partially devolved to the Welsh Government following the recommendations of the Silk Commission (Commission on Devolution in Wales, 2012). The Corporation Tax (Northern Ireland) Bill was published in January 2015 and will allow for Corporation Tax revenues to be devolved to the Northern Ireland Assembly from 2017. Tax devolution inevitably implies some reduction in the level of block grant transfer to the DGs from the UK Government.

Nonetheless, a substantial level of block grant transfer from the UK to the devolved governments will continue to be necessary to address the imbalance between revenue raising and spending by the DGs, so the question of how this grant should be allocated remains. Prior to the Scottish independence referendum in 2014, leaders of the main UK parties 'vowed' to retain the Barnett Formula throughout the next parliament, but beyond this there is likely to be further pressure to reconsider how grant is allocated to the DGs. The UK Government has recently announced the introduction of a 'funding floor' to protect Welsh relative funding, and by implication this will presumably require some assessment of Wales' relative spending needs to determine this floor.

In fact, needs assessment formulae are already used extensively to allocate resources within the DGs to health boards, local government and schools (Smith, 2006; National Audit Office, 2011). However,

'English' spending, the per capita spending increment is the same across administrations, and thus the effect of the different initial spending levels should become proportionately less over time. However, it is clear that convergence has not occurred as quickly as would have been expected, especially for Scotland, due to the success of the devolved territories in periodically bargaining for additional grant increments outwith the operation of the Barnett formula (Christie and Swales, 2010). 
a major argument used against using needs formula to allocate resources to the DGs is that needs assessment is inherently subjective, so that it will be impossible for the DGs to agree on a needs assessment formula (McLean and McMillan, 2005; Midwinter, 2002).

This paper tests the hypothesis that the UK and devolved governments would be unable to agree on an assessment of spending needs, using spending needs for compulsory school age education as an application. Specifically, the paper compares the formula used by the UK government to allocate education resources across local authorities (LAs) in England, with the formula used by the Scottish Government to allocate education resources across LAs in Scotland ${ }^{2}$. This is done by applying each formula in turn to every UK LA to calculate its relative spending need on each formula. Then, within each DA, the spending needs for each LA are summed to calculate the relative spending needs of each DA as a whole according to both formulae.

The rationale for this analysis is to compare how the English and Scottish formulae assess the relative spending needs of different DGs for school-age education. The more similar their assessments are, the greater is the potential for agreement on a spending needs formula to replace Barnett. This is not to say that a Barnett replacement should use either the English or Scottish formulae for assessing education spending needs, but rather to identify where disagreements around needs assessment are likely to arise, and the potential magnitude of any such disagreements.

This paper follows previous work which has compared the way that health spending needs are assessed in England to the way they are assessed in Scotland (Ball, et al., 2015). Ball et al. demonstrate that the English and Scottish health allocation formulae provide similar estimates of the relative spending needs of the DGs. The similarity is perhaps surprising, as it follows over ten years of devolution, during which time the countries have pursued different policies regarding their respective health services. This indicates that the estimates of relative spending need may be less contestable than is sometimes suggested at least for health, which accounts for around one third of devolved spending in each DA.

We focus in this paper on school-age education spending, partly because it is a major area of devolved spending, accounting for $15-23 \%$ of devolved government spending in each DA, and partly because there is already a long history of using needs formulae to allocate resources for education within the UK. England has used a variety of school funding formulae since 1981; Scotland has used

\footnotetext{
${ }^{2}$ In the remainder of this paper, we use the term LA to refer to local authorities which provide education services, of which there are some 150 in England, 32 in Scotland, 22 in Wales, and 5 in Northern Ireland.
} 
its current system of formula-based allocations to LAs since 2000. The reasons for comparing England's education formula with Scotland's (rather than Wales' or NI's education formulae) include that Scotland has an education system that is completely independent from that of England's (Wales, NI and England share the same GCSE qualification system) and thus it might be hypothesised that Scotland's spending needs formula is most likely to differ from England's. Furthermore, it could be argued that the Scottish Government is able to exercise greater leverage in inter-governmental negotiations with the UK Government than the Welsh and NI Governments are; thus any differences between Scotland's and England's resource allocation systems are more likely to prove an obstacle to agreeing a needs based replacement for the Barnett formula.

The remainder of the paper is structured as follows. Section 2 describes patterns of actual education spending across the UK territories. Section 3 describes the process for allocating education resources to LAs (and subsequently, to schools) in England and in Scotland, and highlights some current debates around schools funding. Section 4 sets out in more detail the formulae currently used in England and in Scotland to allocate education resources to LAs. Section 5 describes our approach to comparing the English and Scottish formulae. The results are presented in Section 6, focussing on how the English and Scottish formulae estimate the relative education spending needs of the DGs. Section 7 concludes.

\section{Education spending in the UK territories}

Table 1 shows some statistics on education spending per pupil in the DGs. These figures are derived from total spending figures given by PESA (HM Treasury 2013) and from data on primary and secondary pupils enrolled in state schools from the Pupil Censuses managed by the education departments in each territory. To ensure comparability, we have controlled for the somewhat different start dates for compulsory school age education across the territories by looking at expenditure per pupil in all non-special state schools between the ages of 5-15 years.

Spending per pupil is shown in Row A. Row B gives these results as indexes, with England set at 1.000. Scotland, at 1.018 , spends $1.8 \%$ more per pupil than England, and Wales, at 0.941 , spends $5.9 \%$ less than England. NI has an index of 0.707 , implying that it spends $29.3 \%$ less per pupil than England. NI's result seems surprising, but its robustness can be checked in two ways.

First, we consider whether the result stems from an erroneous estimate of pupil numbers. To do this, we repeated our calculations using ONS data on the population aged 5-15 in each territory as the denominator, instead of pupil numbers. Doing this results in only a slight increase in estimates of 
spend per individual in all three DGs, relative to spending in England (row C), and does not radically alter the estimate of $\mathrm{Nl}^{\prime} \mathrm{s}$ relative spending. The slight increase occurs because a higher proportion of pupils attend private (non-state funded) schools in England relative to the DGs, so the difference between the estimates of state school pupils and all individuals aged 5-15 is greater for England than for the DGs.

Second, we consider whether there may be inconsistencies in how spending on primary and secondary education, published in PESA (HM Treasury 2013), is collated across the territories. To do this, we combine PESA's estimates of spending on primary and secondary education with its estimates of spending on 'subsidiary services to education', 'education not definable by level' and 'education not elsewhere classified' (we continue to exclude estimates of spending on pre-primary and post-secondary education). With this wider definition of education spending, our estimated figures for spending per pupil, indexed to English per pupil spending (row D), fall to 1.010 for Scotland, rise to 1.048 for Wales, and rise substantially to 0.914 for NI. This indicates that a substantial part of the apparent per pupil funding 'deficit' identified above for $\mathrm{NI}$ is simply due to a higher proportion of NI's education spending being classified in one of these more general spending categories.

TABLE 1

Spending on primary and secondary education (2009/10)

\begin{tabular}{lrrrr}
\hline & England & Scotland & \multicolumn{1}{c}{ Wales } & \multicolumn{1}{c}{ NI } \\
\hline A: Spending per pupil & $f 8,652$ & $£ 8,806$ & $£ 8,138$ & $f 6,115$ \\
B: Index of per pupil spending (England = 1) & 1.000 & 1.018 & 0.941 & 0.707 \\
$\begin{array}{l}\text { C: Index of spending per individual aged 5-15 } \\
\text { (England = 1) }\end{array}$ & 1.000 & 1.059 & 0.985 & 0.748 \\
$\begin{array}{l}\text { D: Index of per pupil spending - wider definition } \\
\text { (England = 1) }\end{array}$ & 1.000 & 1.010 & 1.048 & 0.914 \\
$\begin{array}{l}\text { E: Index of education spending per head (England = } \\
\text { 1) - wider definition }\end{array}$ & 1.000 & 0.997 & 1.092 & 1.111 \\
\hline
\end{tabular}

Sources: Spend data from Public Expenditure Statistical Analysis (HM Treasury, 2012); Population estimates from ONS; Pupil data from individual territory Pupil Censuses

In summary, differences in education policy and data collection methods make definitive comparisons of spending per pupil across the UK territories difficult, a fact that has been noted by others (Bain, 2006). Nonetheless, it is apparent that $\mathrm{NI}$ spends notably less on education per pupil than the other DGs territories, even if we take the wider definition of pupil spending (row D). This is chiefly because the Barnett formula is based on a per head of population basis with no other adjustment for spending need. NI's education spending per head of total population is about $11 \%$ 
higher than that of England (row E), but this falls to at least 8\% lower than English spending on a per pupil basis, because NI's demographic is much 'younger' than the rest of the UK.

\section{Allocating education resources by formula}

Education funding formulae are used in at least $13 \mathrm{EU}$ countries (Fazekas, 2012). These formulae typically aim to achieve horizontal equity, so that schools with the same characteristics are funded at the same level, and to do this in a way which is transparent and efficient (Levačić, 2006). Although they differ in their precise form, education formulae typically include a basic pupil allocation (often differentiated by grade level), pupil-specific factors for special education needs, a number of school specific indicators to reflect structural factors that a school cannot alter, and components to reflect the type of curriculum or provision offered by the school (Smith, 2006; Levačić, 2006).

Education funding formulae have been used in the UK since the 1960s. The formulae have evolved through many iterations during this time, although many of the current debates around their design also arise in other countries which use such formulae. The key debates in the UK context include: whether the central government should use formulae to fund schools directly or to fund LAs which then use their own allocation mechanisms for funding schools in their area; the extent to which funding formulae should operate on the basis of inputs (e.g. numbers of pupils with given characteristics) or some measure of outcome; the level of resources that should be allocated to address educational disadvantage; and the autonomy that individual schools should have in deciding how these resources are spent. The rest of this section reviews some of the recent changes to school funding in England and Scotland, and describes some of the current debates.

Between 1997 and 2006, LAs in England received funding for school-based education via the Revenue Support Grant (RSG). The amount of RSG allocated to each LA was based on an assessment of the LA's spending needs for a range of service blocks - including education, social services, roads, etc. - and also on the LA's ability to raise income through taxes on property. The RSG was not hypothecated, so the LA was not obliged to match its actual spend on each block to its assessed need for that block. Spending needs were estimated using the so-called Formula Spending Share (FSS) approach. The FSS for education is described in the following section.

In 2006-07, there was a major change to the way each LA's education was funded, with the introduction of the Dedicated Support Grant (DSG), a specific (ring-fenced) grant which the LA must spend on education. Although it cannot spend less on education than it receives through the DSG, it can spend more by using other sources. 
DSGs are largely calculated on the 'spend-plus' methodology, whereby grants equal a flat-rate increase on the previous year's allocation, adjusted for changes in pupil numbers. The overall DSG budget can also change from year to year to reflect changes in policy responsibilities of LAs or schools (in 2014/15 for example there was a reduction to DSG to reflect the removal of schools from their role in the national energy efficiency scheme, but an addition to DSG to reflect schools' new responsibilities in assessing newly qualified teachers); these additions and subtractions however tend to be made on a per pupil basis, and do not affect relative per pupil allocations. Thus although the DSG allocations are not directly informed by current estimates of LA education spending needs, the pattern of allocations of DSG to LAs is implicitly predicated on the spending needs of LAs as estimated by the former FSS model; we demonstrate this point empirically later in the paper.

Under the SSA/FSS approach, LAs were free to allocate funds between schools within their jurisdiction as they choose. LAs used their own formulae for allocating their grant to schools within their jurisdiction. But because different LAs used different funding formulae, schools with similar characteristics could receive widely differing levels of per pupil funding (Chowdry and Sibieta, 2011).

To address this issue, the government aims to introduce a national funding formula for schools, rather than LAs, arguing that a national formula for schools would be fairer, simpler and more transparent than the existing system. The government plans to introduce such a formula in the next Parliament (post 2015), but meanwhile, as an interim measure, in 2013/14 the government introduced guidelines as to how LAs should allocate DSG resources to schools. This guidance specifies two mandatory factors which LAs must use in allocating grant to schools (pupil numbers and a measure of education deprivation), and identifies a further 10 indicators which LAs may optionally use (these ranging from measures of sparsity to measures of prior to attainment). A 'Minimum Funding Guarantee' protects those schools that see large negative changes in their budgets as a result of application of the new guidelines (the MFG was set at -1.5\% in 2013/14 and $2014 / 15$, and ensures that funding per pupil for any school cannot drop by more than $1.5 \%$ in any one year).

In a further attempt to move towards a new national formula, for 2015/16 the government has allocated an additional $£ 390 \mathrm{~m}$ of schools funding to LAs on the basis of a new needs formula. Although this $£ 390 \mathrm{~m}$ allocation is relatively small in the context of an overall DSG budget of $£ 40 \mathrm{bn}$, and thus is more an augmentation of the existing formula rather than representing a wholly new national formula, the government heralded the arrangement as 'the first time in a decade that funding has been allocated to local areas on the basis of the actual characteristics of their pupils and 
schools, rather than simply their historic levels of funding'. The components of this formula are described in more detail in Section 6.

A further important change to school funding was the introduction of the pupil premium in 2011. This provides a fixed sum for pupils between reception and year 11 classed as having a deprived background, defined chiefly as eligibility for Free School Meals. In 2011 the pupil premium was set at $£ 488$ per eligible pupil, but the value of the premium has since increased substantially, and by 2014/15 had reached $£ 1300$ for Primary pupils and $£ 935$ for Secondary pupils (bringing total expenditure to $f 2.5 \mathrm{bn})$. The pupil premium is allocated to schools directly, rather than to LAs, and can thus be seen as another part of the move towards a national school funding formula over which LAs have little control.

The Scottish system of funding education is similar to the system that operated in England before the DSG was introduced. The Scottish Government allocates a block grant to each of the 32 Scottish LAs. Each LA's grant allocation is based on an assessment of its spending need, known as its Grant Aided Expenditure (GAE), and its capacity to raise income through taxes on property. Each LA's GAE is broken into a number of service areas, of which education is the largest. The block grant is not hypothecated, so each LA can spend more or less on education than the figure calculated by the education GAE. As in England, LAs then allocate grant to schools within their jurisdiction.

In NI, schools are funded directly by the Department of Education NI according to a needs-based formula known as the Common Funding Scheme. Introduced in 2005, this Scheme allocates resources to schools based on age-weighted pupil numbers, school size, social disadvantage, attainment, teacher salaries, and other pupil characteristics (Department of Education Northern Ireland, 2013). The formula has undergone periodic changes, most recently an enhanced emphasis on pupils who are socially deprived. A separate formula known as ARNE (Assessment of Relative Needs Exercise) is used to allocate resources to the five Education and Library Boards for the provision of local education services that are not managed by individual schools.

In Wales, a block grant is allocated to LAs using Standard Spending Assessments (SSA). The SSA is an assessment of LA spending need across a range of service areas, including education (Welsh Government, 2012). The education element of the SSA is based on a variety of measures of pupil numbers, school size and sparsity, and measures of social deprivation. The approach is thus very similar to the Scottish GAE system, and similar to the English FSS system that operated prior to 2008. 
In summary, both England and Scotland have, until recently, allocated unhypothecated grant to LAs to spend on education, and allocate to schools, as they see fit. Although the schools grant in England is now ring-fenced, there are similar concerns in both countries as to the variation in resources received by schools of similar characteristics. Both England and Scotland are therefore investigating the potential for more nationally-based allocation arrangements that would in effect reduce the level of freedom of LAs to determine how education resources are spent (Department for Education, 2012; Cameron, 2012).

Both the English and Scottish formulae have been developed by predicting existing expenditure patterns from need and cost influencing indicators. Longer term, there is interest in the possibility of allocating resources to schools in such a way as to achieve explicit outcomes or levels of attainment. Bramley et al. (2011) demonstrate how such an approach might be applied, but it is clear that there remain difficulties with the outcome-based approach both in terms of how attainment is defined, and the uncertainty of the causal relationship between education spending and student performance (Dearden and Vignoles, 2011; Gibbons, et al., 2012; Holmlund, et al., 2010; Hanushek, 2010; Machin, et al., 2010). It is clear therefore that needs based formula funding will continue to be used in England and Scotland to allocate school resources to local authorities. The main debates are around the extent to which local authorities should have autonomy to deviate from national formulae when passing resources on to schools, and the extent to which there is an appropriate balance between transparency and sensitivity to local need (i.e. simplicity and complexity).

\section{Comparing the FSS and GAE}

Both the English FSS and the Scottish GAE systems attempt to measure the relative spending needs of LAs for school education, and allocate grant to LAs on the basis of these assessments. In this section we outline the structure of the English FSS and Scottish GAE formulae for allocating schools grants, and describe the data used by the two formulae. The aim of the paper is to compare how similar the pattern of resources made by each formula is, and our method for doing so is described in Section 5. In section 6 we also describe the 'Fairer Schools Funding' formula that is being used to allocate some additional resources in England in 2015/16.

It might be questioned why we place so much emphasis on comparing GAE with FSS, given that FSS has not been formally applied since 2005/6. The answer is that FSS remains the formula through which the spending needs of English LAs are implicitly assessed, given the use of the 'spend-plus' methodology for uprating allocations that underpins the DSG. Figure 1 plots the actual education 
funding allocation per pupil made to each English LA in 2014/15 through the DSG and the Pupil Premium $^{3}$ - expressed relative to the English per pupil average allocation of 1 - against the per pupil relative need score for each English LA as assessed by the FSS and applied to LA data from 2009/10. There is a very close relationship between the two 'scores'; the regression line has a constant term that is not significantly different from zero and a slope coefficient that is not significantly different from one, implying that the two approaches effectively allocate resources in an identical way on average.

There is some variation around this relationship which is to be expected. Some LAs would not have been funded at the level implied by the FSS needs assessment in 2005/6 given damping adjustments. Damping adjustments are made to LAs' allocations so that individual LAs do not experience large shifts in funding from one year to the next, even if, for historic reasons, they currently receive a much higher level of resources than is implied by the assessment of spending need). Thus even if all that had happened since $2005 / 6$ was that each LA had seen an equivalent proportion increase in its per pupil funding there would not be a perfect match between the assessment of need in 2005/6 and actual funding in 2014/15 (in fact, we would not expect a perfect correlation between the assessment of need in 2005/6 and actual funding in 2005/6). In summary, the FSS is a good proxy for the pattern of resource distribution in 2014/15.

\section{FIGURE 1}

\section{Comparing the DSG and Pupil Premium allocation 2014/15 with the FSS needs assessment}

\footnotetext{
${ }^{3}$ Pupil Premium resources are allocated to schools rather than LAs, but we treat them as if they are allocated to LAs as the Pupil Premium reflects an implicit judgement by the Government as to the spending needs associated with each LA.
} 


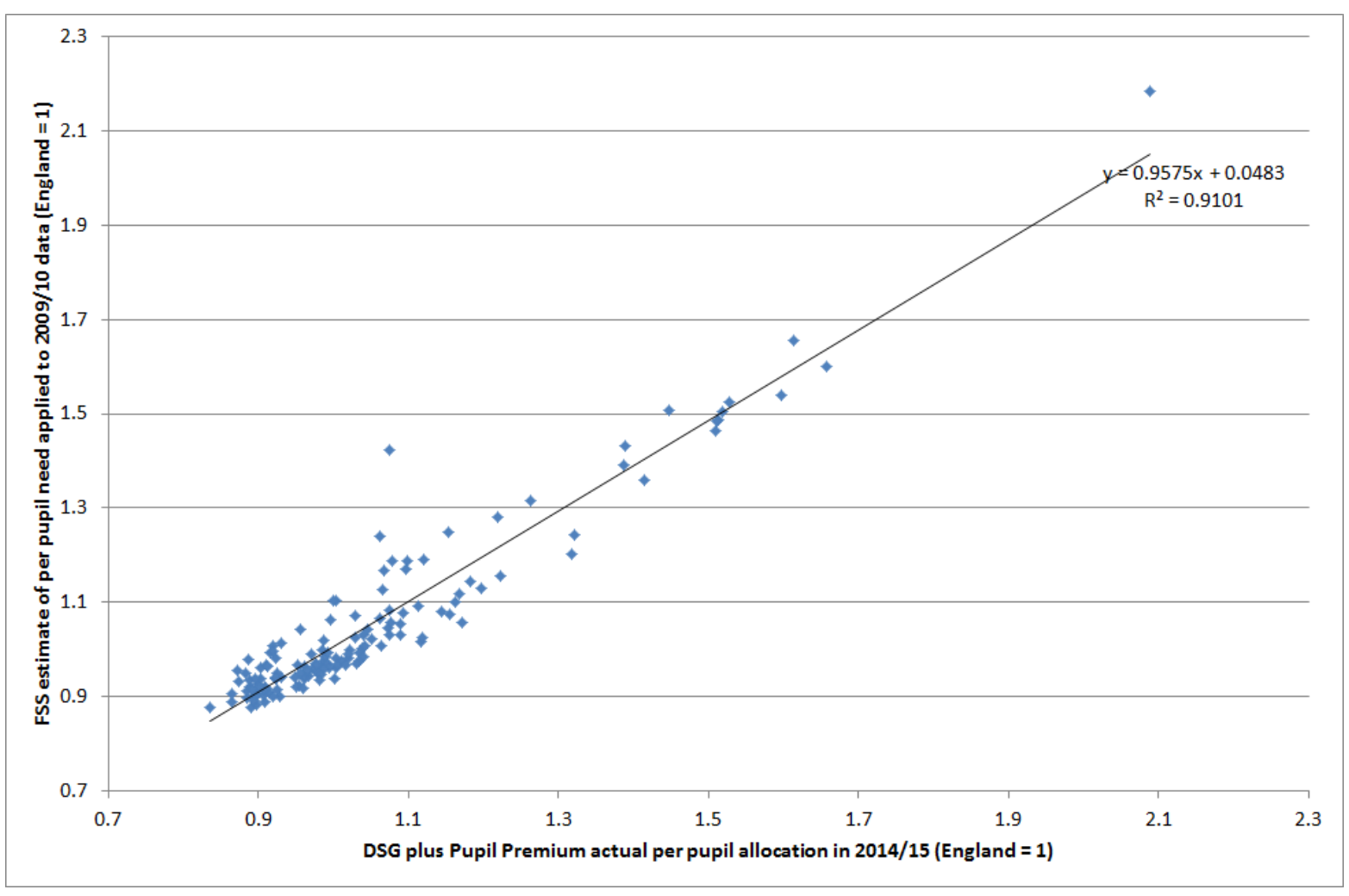

The Scottish education GAE, as applied during the $2008 / 11$ spending period, assesses LA spending needs for compulsory-age education across 13 separate components (Table 2). Three of these components (primary school teaching staff; secondary school teaching staff; and school nonteaching staff and property) account for $68 \%$ of the total allocation. The remaining components include amounts for special education, school transport, school meals, education deprivation.

For each component, LA spending need is derived by reference to a primary indicator and a secondary indicator. The primary indicator is used to allocate the total level of resources available for a given component among Scotland's LAs based on their respective shares of that indicator. For example, the primary indicator for the Primary School Teaching Staff component is the number of primary school pupils. If a given LA has $5 \%$ of Scotland's primary school pupils, then it will initially be allocated $5 \%$ of the $£ 902$ million available for this component. The secondary indicator is used to redistribute those initial shares between authorities based on needs additional to the per capita amount. In the primary school teaching staff component for example, the secondary indicator adjusts the initial per pupil shares based on a measure of rurality and school size. The strength of the secondary indicator relative to the primary indicator varies depending on the component in question. A LA's total spending need for education is derived by summing its needs over each component. 
In the English education FSS (last used in its pure form in 2006) there are six sub-blocks within the education service block that pertain to compulsory school-age education. These are:

- Primary education

- Secondary education (up to age 15)

- High cost pupils

- Schools damping

- Local Education Authority (LEA) central functions

- LEA damping

The two damping sub-blocks, schools damping and LEA damping, are designed to ensure that each school/LEA receives a minimum increase in funding, taking into account previous grant, and are thus not directly measures of spending need per se.

Within each block, LAs receive a 'basic amount' for each individual of the respective client group, plus one or more 'top-ups' (Table 3). For the Primary education block for example, LAs received a basic amount of $£ 2,266$ for each primary education pupil, plus top-ups for 'additional education needs' and 'sparsity'. The level of the top-up for each LA was calculated by reference to various indicators. The primary education additional needs top-up was calculated using data on the number of pupils whose mother tongue is not English, the number of children of income support or income based jobseeker's allowance claimants, and the number of children of working families tax-credit claimants. Additionally, the English FSS contained an area cost adjustment (ACA) which compensates LAs which face particularly high wage and other factor costs (principally those in London and the southeast region).

TABLE 2

Summary of indicators used in Scottish education GAE for 5-15 year olds

\begin{tabular}{ll}
\hline \multicolumn{1}{c}{ Component } & \multicolumn{1}{c}{ Indicators used } \\
\hline Primary school teaching staff & $\begin{array}{l}\text { Primary sector pupils } \\
\text { Percentage pupils in small schools }\end{array}$ \\
\hline Secondary school teaching staff & $\begin{array}{l}\text { Secondary sector pupils } \\
\text { Island LA adjustment }\end{array}$ \\
\hline $\begin{array}{l}\text { School non-teaching staff, } \\
\text { property etc }\end{array}$ & $\begin{array}{l}\text { All education authority pupils } \\
\text { Urban settlement pattern }\end{array}$ \\
\hline Special education & Population aged 2-19 \\
\hline School transport & $\begin{array}{l}\text { Population aged 5-15 } \\
\text { Population dispersion }\end{array}$ \\
\hline School meals & Pupils taking meals \\
Income support dependents per 1000 aged 0-19
\end{tabular}




\begin{tabular}{|c|c|c|}
\hline \multicolumn{3}{|c|}{$\begin{array}{l}\text { Hostel places per } 1000 \text { pupils } \\
\text { Income support dependents per } 1000 \text { aged 0-19 }\end{array}$} \\
\hline School security & \multicolumn{2}{|c|}{$\begin{array}{l}\text { Number of pupils } \\
\text { Number of establishments }\end{array}$} \\
\hline Gaelic education & \multicolumn{2}{|l|}{ N/A } \\
\hline Teachers for ethnic minorities & \multicolumn{2}{|c|}{ Number of ethnic minority pupils } \\
\hline Education deprivation & \multicolumn{2}{|c|}{$\begin{array}{l}\text { Primary schools - weighted free meals registration } \\
\text { Secondary schools - weighted free meals registration }\end{array}$} \\
\hline National Priorities Action Fund & \multicolumn{2}{|c|}{ Government-determined } \\
\hline Former Excellence Fund & \multicolumn{2}{|c|}{ Share of previous settlement } \\
\hline \multicolumn{3}{|c|}{ Notes: Indicators in italics are secondary indicators. Source: Scottish Government (2008) } \\
\hline \multicolumn{3}{|c|}{ TABLE 3} \\
\hline \multicolumn{3}{|c|}{ Summary of indicators used in English education FSS for 5-15 year olds } \\
\hline Sub-block & Top-ups & Indicators \\
\hline \multirow{4}{*}{ Primary education } & Basic amount & Pupils aged 5-10 \\
\hline & $\begin{array}{l}\text { Additional education needs } \\
\text { top-up }\end{array}$ & $\begin{array}{l}\text { Pupils whose mother tongue is not English } \\
\text { Children of IS/ income based JSA claimants } \\
\text { Children of working families tax-credit claimants }\end{array}$ \\
\hline & Sparsity top-up & A function of population density \\
\hline & Area Cost Adjustment (ACA) & Based on earnings data \\
\hline \multirow{3}{*}{ Secondary education } & Basic amount & Pupils aged $11+$ \\
\hline & $\begin{array}{l}\text { Additional education needs } \\
\text { top-up }\end{array}$ & $\begin{array}{l}\text { Pupils in low-achieving ethnic groups } \\
\text { Children of IS/ income based JSA claimants } \\
\text { Children of working families tax-credit claimants }\end{array}$ \\
\hline & ACA & As above \\
\hline \multirow[t]{2}{*}{ High-cost pupils } & Basic amount & $\begin{array}{l}\text { Low birthweight births } \\
\text { Children of IS/ income based JSA claimants } \\
\text { Population aged 3-15 }\end{array}$ \\
\hline & ACA & As above \\
\hline \multirow{5}{*}{ LEA central functions } & Basic amount & Pupils aged 3-18 \\
\hline & Deprivation top-up & Children of IS/ income based JSA claimants \\
\hline & Sparsity top-up & A function of population density \\
\hline & LEA fixed cost amount & Fixed amount per LA \\
\hline & ACA & As above \\
\hline
\end{tabular}

Notes: although the indicators used are often the same across different sub-blocks, the weights attached to indicators vary. In some cases, the top-up amounts are calculated as a non-linear function of the indicators. Source: ODPM (2005)

V.

\section{Approach}

The analysis in this paper involves applying the English FSS and Scottish GAE education formulae in turn to all LAs in the UK. The aim is to identify the relative spending need of each LA for compulsory school age education if it was treated as an English LA, and compare this with the estimate of its relative spending need for compulsory school age education if it was treated as a Scottish LA. 
To compare FSS and GAE, the data for the factors listed in Tables 2 and 3 were collated for each LA and applied with the appropriate weightings. Most of the data required on pupil and school characteristics were available from the Pupil Censuses produced annually by the education departments in each territory (for example, data on pupil numbers, free school meal eligibility, pupil ethnicity, school size). Data on wider population and labour market characteristics (for example benefit claimant rates, earnings data) were available from national statistical offices, as were data on settlement patterns to inform various indicators of rurality/sparsity.

For each territory, the data on schools and pupil numbers relate to all publicly funded schools (including academies, foundation schools, etc.), but exclude special schools and private schools ${ }^{4}$. More information on our data sources and assumptions are available from our two methodology papers (Ball, et al., 2012a; Ball, et al., 2012b).

All data relate to the $2009 / 10$ academic year, so the results indicate the relative spending needs of LAs in that year, had the formulae been applied in that year. In other words, we consider what the relative spending needs would be for each LA if the English 2005/6 needs formula was applied to LAs in 2009/10 Likewise we consider what the relative spending needs of each LA would be if the Scottish needs formula for 2009/10 was applied in that year.

The 'damping' elements of the formulae are adjustments that are made to LAs' allocations so that individual LAs do not experience large shifts in funding from one year to the next. The MFG mentioned in the previous section is an example of a damping element - the MFG ensures that no school experiences a drop in funding of more than $1.5 \%$ in any one year, regardless of the extent to which funding formulae suggest that that school might be being over-funded currently. We exclude damping elements from the analysis as we are interested in estimating LAs' existing relative spending needs, without the bias introduced by conditioning LA resource allocations on past levels of grant.

The data were applied to all education LAs in the UK (of which there are 150 in England, 32 in Scotland, 22 in Wales, and five in NI). The rationale for applying the formulae at LA level was twofold. First, there are elements of both the English and Scottish education formulae that are based on thresholds (i.e. where LAs above or below a particular threshold receive no resources, whilst other LAs receive a sum that is a function of a particular indicator). Thus the only reliable way of assessing

\footnotetext{
${ }^{4}$ In England, academies and foundation schools are publicly funded schools that are outwith control of the local authority and are funded directly by the Education Funding Agency. However, for the purposes of assessing the overall education spending needs of the UK territories, we include them in our analysis of the spending needs of each LA.
} 
the relative spending needs of each territory is to aggregate the results from each $L A$ within the territory. Second, having results at LA level allows us to make more interesting comparisons about how the two formulae assess relative needs.

When applying the Scottish formula, all LAs were treated 'as if' they were Scottish LAs, and it is assumed that the transition from primary to secondary school occurred at year 8. Similarly, when applying the two English formulas, all LAs were treated 'as if' they were English, and the transition from primary to secondary school occurred in Year 7. Given that the paper is motivated by the desire to understand the DG's spending needs for compulsory-age school education (i.e. for pupils aged 515), elements of the formulae that relate specifically to pre-school nursery education, and funding associated with sixth-form colleges, are excluded. This enables the analysis to compare on a like-forlike basis the spending needs associated with compulsory age schooling, having abstracted from issues around pre-school and post-16 education.

When we apply FSS and the possible new simpler English formula, we are comparing the spending needs of all UK LAs against some measure of average per pupil need in England; and when we apply GAE, we are comparing the spending needs of all UK LAs against average per pupil needs in Scotland. In the results, we then rescale the GAE estimates of relative need so that they are expressed relative to per pupil spending needs in England.

\section{Results}

\section{Comparing formulae results: UK territories}

Table 4 shows the results of applying the English and Scottish education formulae to the UK territories. Row A shows the relative per pupil spending need of the UK territories (expressed relative to English per pupil spending needs of 1 ) according to the English FSS formula. Row B shows the relative per pupil spending needs of the UK territories according to the Scottish GAE formula (again expressed relative to English per pupil spending needs of 1).

The two formulae are reasonably similar in how they assess the per pupil spending needs of the DGs, and perceive little overall difference in the range of per pupil spending needs across territories. The English FSS assesses the DGs spending needs to range from 0.977 to 0.988 (i.e. per pupil need in the DGs ranges from 2.3\% below England's to 1.2\% below England's). The Scottish GAE assesses them to range from 0.984 to 1.003 (i.e. from 1.6\% below England's to $0.3 \%$ above England's). 
Furthermore, both formulae agree on the rank of the devolved territories with regard to per pupil spending need. They assess $\mathrm{NI}$ to have the lowest per pupil spending needs, Wales to have the second lowest spending needs, and Scotland to have the highest spending needs of the devolved territories.

In the English FSS formula, NI has relatively low needs for three main reasons: it has relatively few LAs (and so gets a lower per pupil allocation from the LA fixed amount); it has a low proportion of ethnic minority pupils; and it receives no allocation from the area cost adjustment (ACA). NI's need score is also relatively low according to the Scottish formula. One reason for this is that, although $\mathrm{NI}$ has a relatively high level of overall deprivation, the Scottish formula allocates more resources to areas where deprivation is concentrated in particular schools, on which measure NI seems to do relatively less well. The measure of education deprivation is discussed in a subsequent sub-section.

Overall there appears relatively little difference in the assessed per pupil spending needs of the DGs, and certainly less difference than is observed in current actual per pupil spending. Comparing the results from rows A-B to actual per pupil spending on education (row $C$ ) reveals that Welsh education spending per pupil looks generous relative to need, while education spending in NI appears low relative to need.

Rows D-E of Table 4 express the results in terms of spending need per total population, as opposed to per pupil. The spending needs per population are markedly different, given differences in the demographic composition of the territories. $\mathrm{NI}$ in particular has a high proportion of school-age pupils relative to the rest of the UK, while Scotland has a relatively low proportion. On a per capita basis, Wales' education spending need rises to between 2.3\% (FSS) to 3.8\% (GAE) above England's. Scotland's per capita need is slightly below England's, while NI's is significantly above. There remains good comparability between the three formulae - $\mathrm{NI}^{\prime}$ s assessed need varies from $18.7 \%$ to $19.6 \%$ above England's, while Scotland's need varies between $1.0 \%$ to $2.5 \%$ below England's.

Given that the FSS contains an adjustment for factor costs, the ACA, but the Scottish formula does not, it is interesting to consider how different the FSS scores would be if the ACA was excluded. Row F of Table 4 shows the relative needs estimates of the FSS formula (per pupil) if the ACA is excluded from all its sub-blocks, while Row G excludes the ACA from the FSS estimate of spending need per capita. Excluding the ACA raises the relative per pupil need scores of Wales, Scotland and NI to $1.017,1.017$ and 1.012 respectively (the relative need of the devolved territories rises because of the reduction in to the assessed need of local authorities in the south east of England). Expressing 
these results on a per capita basis somewhat lowers the relative needs of Scotland, while raising the relative needs of Wales and NI.

TABLE 4

Comparing the spending needs of the UK territories (England $=1$ )

\begin{tabular}{lcccc}
\hline & England & Wales & Scotland & NI \\
\hline $\begin{array}{l}\text { Per pupil need: } \\
\text { A: English FSS }\end{array}$ & 1.000 & 0.981 & 0.988 & 0.977 \\
B: Scottish GAE & 1.000 & 0.996 & 1.003 & 0.984 \\
& & & & \\
\hline C: Actual per pupil spend & 1.000 & 1.048 & 1.01 & 0.914 \\
\hline Per capita need: & & & & \\
D: English FSS & 1.000 & 1.023 & 0.975 & 1.187 \\
E: Scottish GAE & 1.000 & 1.038 & 0.99 & 1.196 \\
\hline Excluding ACA from FSS: & & & & \\
F: English FSS (per pupil) & 1.000 & 1.017 & 1.017 & 1.012 \\
G: English FSS (per capita) & 1.000 & 1.060 & 1.004 & 1.230 \\
\hline
\end{tabular}

\section{Comparing LAs' relative needs for compulsory school-age education}

To further compare the patterns of allocations made by the English FSS and Scottish GAE formulae, Figure 2 compares the per capita allocations they make to each LA in the UK. Each LA's need score according to the English FSS is plotted on the x-axis, while LAs' need scores according to the Scottish GAE are plotted on the $y$-axis. The dashed $45^{\circ}$ line represents the line that LAs would be located on if their relative per capita spending needs were assessed equivalently by the two formulae; points to the left of this line imply that the Scottish GAE formula assesses relative need to be greater than the English FSS formula does, while points to the left imply the converse.

There is a reasonably strong correlation between the two formulae in how the relative education spending needs of individual LAs are assessed. The slope coefficient on the line of best fit between the formulae is 0.89 (we would expect the coefficient to be one if the two formulae assessed needs identically). There is clearly some variation around this average relationship; there is more than a $10 \%$ difference in assessed relative per capita need for 32 out of the 208 LAs when these formulae are compared. 
Much of this variation between the English FSS and Scottish GAE formulae arises because the FSS formula includes an Area Cost Adjustment (ACA) which allocates substantial additional resources to LAs in London and southeast England. Figure 3 plots the same information as Figure 2, but having removed the ACA from the FSS formula. The relationship between the GAE and FSS formulae is now even stronger, witnessed by the higher $\mathrm{R}^{2}$ : there is now more than a $10 \%$ difference in assessed per capita need for only 11 LAs when comparing the two formulae. How should this be interpreted? One argument is to say that the only relevant comparison is between the GAE and the FSS including the ACA, given that the ACA is used as part of the English needs assessment. However, it could also be argued that the only reason that the Scottish GAE formula does not include an ACA is because it does not face the substantial geographic variation in living costs that are observed in England; thus, in comparing the two formulae, what is most important is to compare the assessment of LA needs for the type of LAs that both countries have, which is effectively what is happening in Figure 3.

FIGURE 2

Comparing the per capita allocations to Local Authorities made by the English FSS and Scottish GAE formulae

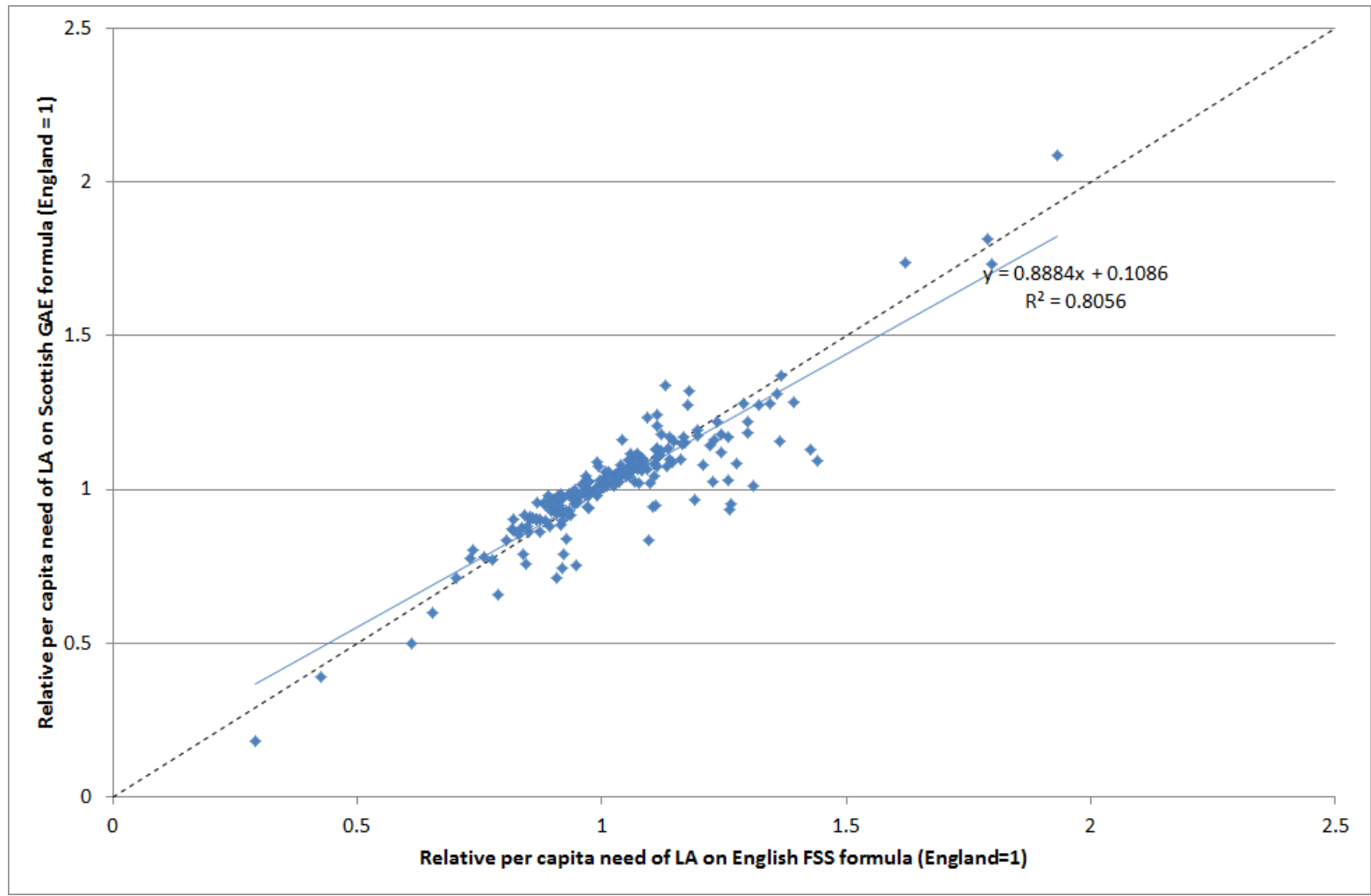

FIGURE 3

Comparing the per capita allocations to Local Authorities made by the English FSS and Scottish GAE formulae (excluding ACA from English formulae) 


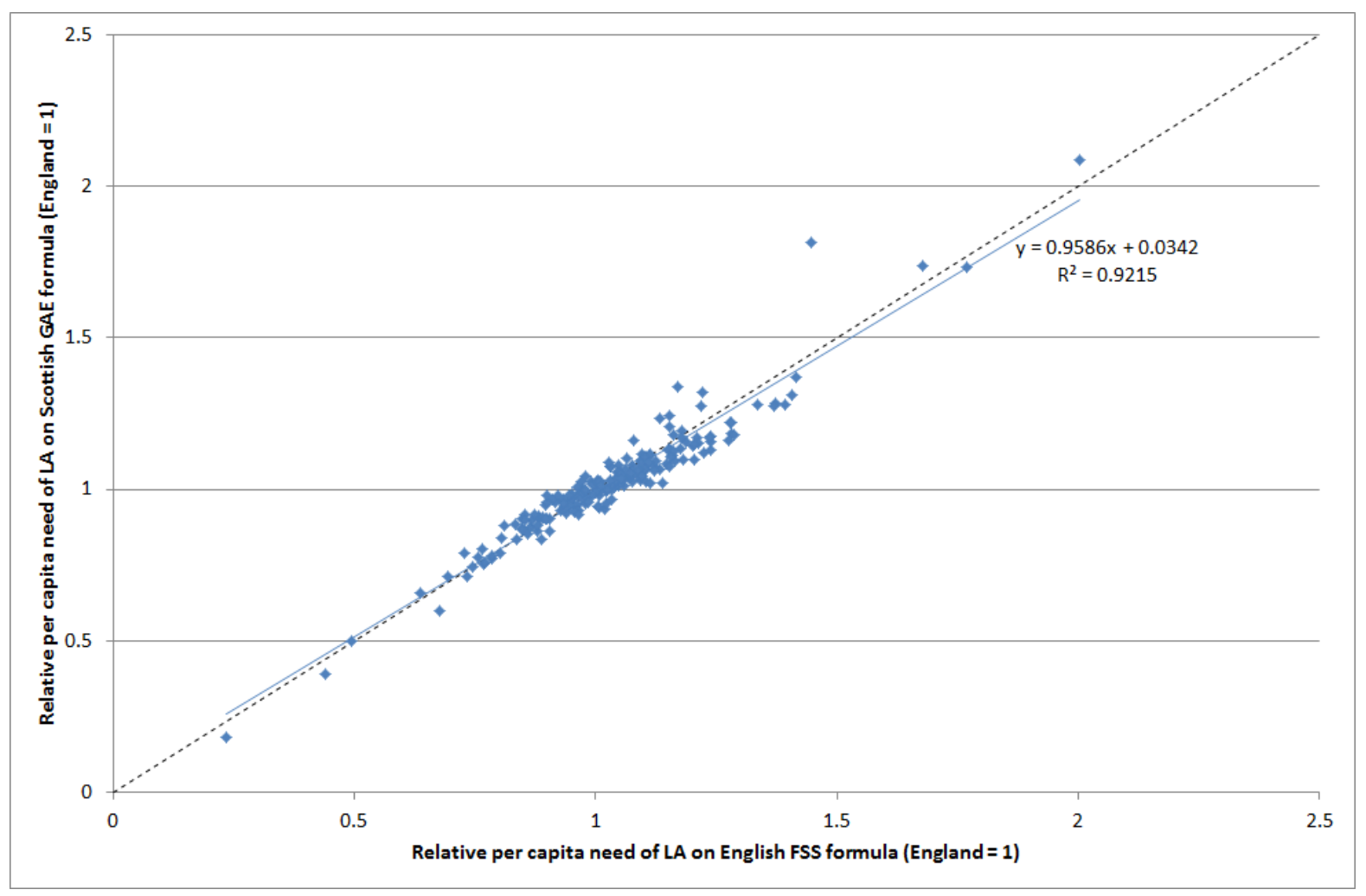

If a formula was introduced to allocate resources to the UK territories, the governments of each territory might come under pressure to use such a formula to allocate resources within their territories. A key question in determining the political viability of such a formula would therefore depend on the extent to which such a formula would result in a different pattern of funding allocations to individual LAs from those observed currently ${ }^{5}$.

Let's assume that politicians have agreed on an education spending needs formula for allocating grant to the DGs which effectively represents a compromise between the Scottish GAE and the English FSS. How different would the pattern of allocations to LAs be if this formula was also used within each territory? For England, we have data on the actual education grants received in 2009/10. Comparing these actual grant allocations on a per pupil basis with the relative per pupil needs assessments derived from our hypothetical 'average' formula reveals that 27 of 149 English LAs would be allocated a per pupil sum that was more than $5 \%$ different from their current per pupil allocation. Although this sounds like a large error, it is important to note that 24 English LAs received in 2009/10 an allocation that was more than 5\% different from their FSS-assessed per pupil need; differences between allocations and assessed need result from the application of damping rules which are designed to ensure that LA allocations do not change abruptly from one year to the next.

\footnotetext{
${ }^{5}$ We are indebted to an anonymous referee for drawing our attention to this point.
} 
For Scotland, it is not possible to ascertain actual grant allocations specifically for education. This is because the GAE education need score is combined with needs assessments for other service areas and an assessment of each LA's ability to raise revenue from taxes on property; the resulting block grant does not explicitly allocate an amount for education. We therefore compare each LA's education need score on GAE with its need score on the hypothetical average formula. This reveals that only two of Scotland's 32 LAs would be allocated a per pupil sum more than $5 \%$ different from their 'actual' allocation, where the 'actual' allocation is taken to be the GAE needs assessment score (these two LAs being Orkney and Shetland).

\section{The 2015/16 English Fairer Schools Funding Formula}

As noted previously, in its allocation of schools funding to LAs in 2015/16, the government has used a needs formula, the 'Fairer Schools Funding' (FSF) formula, to allocate some $f 390 \mathrm{~m}$. The purpose of this funding is to allocate additional resources to the 'least fairly funded local authorities'. To allocate this resource, the government established minimum funding levels that a LA should attract for its pupils and schools in 2015/16 (Table 5). These minimum funding levels are based on the average amounts that LAs used in their own local formulae in 2013/14. The government first calculates the amount each LA would receive via the DSG allocation in 2015/16 given the commitment to fund each LA at the same cash value per pupil as it received in 2014/15. It then applies the minimum funding amounts shown in Table 5 to the relevant number of pupils and schools in each LA to calculate a new total. If this new total is more than the LA's 2014/15 per pupil cash level, the LA's funding is increased to the new level. If the new total is less than the existing cash allocation, the LA's funding remains unchanged.

TABLE 5

2015/16 Fairer Schools Funding Formula

Indicator Amount

Basic per pupil amount

Primary $£ 2,845$

Key stage $3: £ 3,951$

Key stage 4: $£ 4,529$

Deprivation

Between $£ 893$ and $£ 1,974$

Looked after children

$£ 1,009$

Low prior attainment

Primary: $£ 878$ 
English as an additional language

$\begin{array}{ll}\text { School lump sum } & \text { Secondary: } £ 1,216 \\ & \text { Primary: } £ 117,082 \\ \text { Sparsity sum for schools vital to serving rural } & \text { Up to } £ 53,988 \\ \text { communities } & \\ \text { Area Cost Adjustment to increase minimum } & \\ \text { funding in areas with higher labour market costs } & \end{array}$

Sparsity sum for schools vital to serving rural

communities

Area Cost Adjustment to increase minimum

funding in areas with higher labour market costs
Primary: $£ 505$

Secondary: $£ 1,216$

Primary: $£ 117,082$

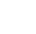

69 of England's 151 LAs receive additional resources as a result of applying the 2015/16 FSF formula. The formula allocates resources in a very different pattern from the existing pattern of allocations, indeed the point of the formula is to correct perceived iniquities in the current pattern. In particular, the new formula tends to benefit more rural areas over inner cities relative to the old formula. This is the result of the inclusion of the sparsity sum, the school lump sum (which in per pupil terms benefits areas with smaller schools) and the new ACA which is calculated using a different methodology and thus allocates relatively fewer resources to high-cost inner city areas. Given that the funding allocated by this formula represents just 1\% of the total DSG allocation in 2015/16, this formula shouldn't be thought of as representing what the government believes a new national funding formula should look like. Indeed, the government points out that LAs are under no obligation to follow this formula when allocating funds to schools within their areas, and that the national funding formula will be a matter for the next spending review. And the overall pattern of allocations made in 2015/16 - including the Pupil Premium - is still very closely approximated by the FSS need formula (Figure available from authors on request).

Nonetheless, it is useful to consider how the 2015/16 FSF formula would allocate resources across the UK territories, if it was used for this purpose. Table 6 shows the results ${ }^{6}$. The 2015/16 formula assesses the relative per pupil spending needs of the DGs somewhat more generously than does either the FSS and the GAE. Row A shows that Wales' relative per pupil needs are around $2.3 \%$

\footnotetext{
${ }^{6}$ Figures in Table 6 are derived by applying the factors in Table 5 to 2009/10 LA data for the same set of LAs as was considered previously. We excluded the element of the formula pertaining to 'low prior attainment' as this is difficult to asses comparatively given differences in pupil assessment across the DGs.
} 
higher than England's, while Scotland's and NI's are each 1\% higher. Row B shows that Wales' relative per capita needs are around 6.7\% higher than England's while NI's are around 22.3\% higher, though Scotland's needs remain about 1\% lower than England's.

TABLE 6

Applying the 2015/16 English Fairer Schools Funding formula to the DGs

\begin{tabular}{lcccc}
\hline & England & Wales & Scotland & NI \\
\hline A: Per pupil & 1.000 & 1.023 & 1.007 & 1.006 \\
B: Per capita & 1.000 & 1.067 & 0.994 & 1.223 \\
\hline
\end{tabular}

\section{Allocating funding for education deprivation}

We now compare how the Scottish GAE and English FSS allocate resources for education deprivation. There is widespread recognition that poverty and socio-economic disadvantage are major influencers of pupil attainment (West, 2009; Glennerster, 2002), and there is significant interest in the extent to which these effects might be mitigated through additional spending. The House of Commons Select Committee on Education and Skills (2003) stated that 'It is unarguable from the evidence presented to us that poverty is the single biggest indicator of low educational achievement'. More recent research demonstrates that there is a considerable attainment gap at school entry between pupils eligible to receive school meals and the rest, and that this gap widens over time (Hills, 2010). There is also evidence that concentrated poverty in particular neighbourhoods can aggravate poor attainment (Glennerster, 2002).

Consequently, both funding formulae contain explicit elements for pupil disadvantage. As shown in Table 3, the FSS formula contains additional education need top-ups within each sub-block, allocating additional funds to LAs in proportion to factors such as the proportion of children living in households receiving unemployment and low-paid benefits. More recently, as described in Section 3, additional resources are now being allocated to schools in England through the pupil premium, with the aim being that 'a disadvantaged background ceases to be a barrier to a young person's attainment' (Department for Education, 2010). The GAE formula allocates additional resources for education deprivation largely through the 'education deprivation' component, which allocates resources to LAs as a function of the proportion of pupils eligible for FSM.

However, it is interesting to note some explicit differences between the English formula and the Scottish formula concerning the allocation of resources for education deprivation. FSS allocates resources in direct proportion to the number of 'disadvantaged' pupils in each LA. In contrast, GAE 
allocates funding for disadvantage in relation to how concentrated disadvantage is in each school ${ }^{7}$. This means that different LAs in Scotland receive very different amounts per pupil eligible for FSM, with Glasgow receiving $53 \%$ of the share of all resources attached to this indicator while some LAs (East Lothian, Midlothian, Western Isles) receive no resources.

To compare how the formulae allocate resources across LAs with different levels of disadvantage, the 208 UK LAs in our analysis were ranked according to the level of deprivation (where deprivation is proxied by the proportion of children living in households claiming income support or jobseeker's allowance $)^{8}$. We then calculated the relative per pupil allocations that each formula would make to LAs in each decile of deprivation.

The results are shown in Figure 4. This seems to suggest that Scotland's GAE is the least redistributive- it allocates relatively more to the least deprived LAs than the FSS, and relatively less to the most deprived LAs. Although this may appear to contradict the preceding discussion around the way in which the Scottish formula concentrates resources in the most deprived LAs, it results from the fact that a relatively small part of the total Scottish allocation is determined by the education deprivation component ${ }^{9}$. Thus it could be argued that the Scottish formula, while progressive, is not particularly redistributive.

FIGURE 4

Per pupil relative funding by deprivation decile

\footnotetext{
${ }^{7}$ Specifically, the indicator is defined as: 'the number of pupils in the top $10 \%$ of schools ranked by the percent of pupils registered for free school meals, expressed for each authority as a percentage of all Scottish pupils in the top $10 \%$ '

${ }^{8}$ The same analysis was performed using eligibility for FSM as the measure of deprivation, yielding virtually identical results to those discussed here.

${ }^{9}$ To test whether this result is an artefact of the ACA in the FSS formula (which might arise if LAs which receive additional resources through the ACA are consistently more deprived than those which do not receive the ACA), we repeated the analysis in Figure 3 having removed the ACA from the FSS formula. This did not materially alter the conclusion that England appears more progressive than Scotland.
} 


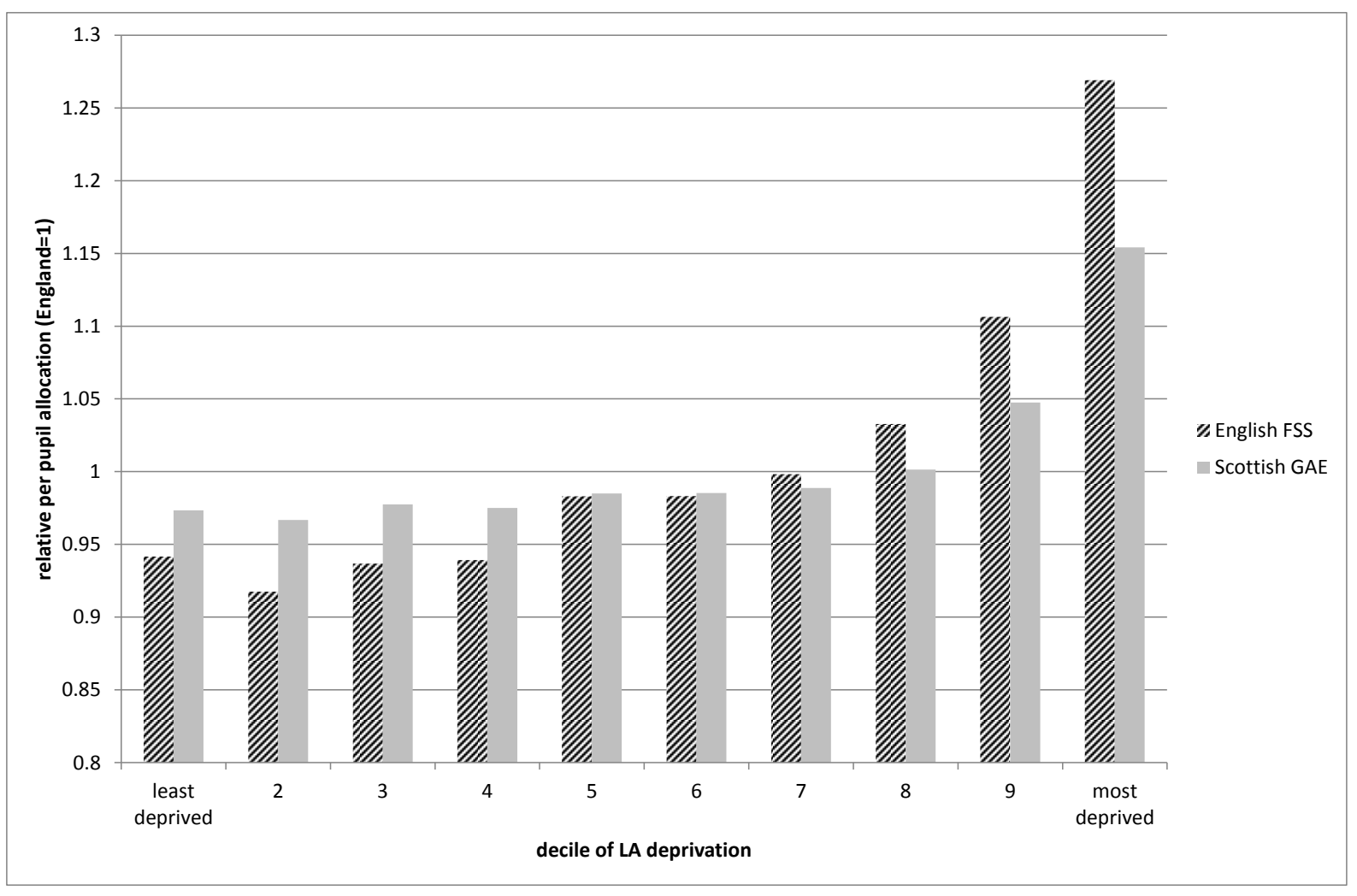

The fact that Scotland is able to take a different approach to the funding of disadvantaged pupils should be seen as a strength of devolution. However, it is difficult to draw conclusions as to which allocation system is most effective at addressing educational disadvantage, as the Scottish and English education systems seem to display similar differences in the level of educational attainment across socio-economic groups (Machin, et al., 2012). Furthermore, the analysis here looks at how resources are allocated to LAs, and LAs themselves might not then pass the education resources that they receive through the education block grant to schools in the same pattern that resources are allocated to LAs nationally. What this discussion does highlight however is how ideological differences in the importance attached to different factors can manifest in different funding formulae.

\section{Conclusions}

Devolution to Scotland, Wales and NI has provided the devolved governments in these territories with the opportunity to pursue different policies. This policy distinctiveness is particularly evident in education, where different curricula and systems of pupil assessment are in place; and policy distinctiveness is also seen in the ways by which the DGs allocate grant to school education within 
their own territories. This ability to pursue policy distinctiveness is both the intention and strength of devolution.

But the significant spending and policy autonomy of the DGs raises challenging questions about how the DGs should be funded. There has long been a widespread dissatisfaction (in England and Wales) with the way in which resources are allocated to the DGs, and repeated calls for the Barnett formula to be replaced by a 'fairer' system of needs assessment. However, a replacement for the Barnett Formula has never been seriously proposed. The reason appears to lie in a belief that the Westminster Government and the DGs would never be able to agree on what a needs-based grant allocation formula might look like.

This paper tests this hypothesis by comparing the way in which the Scottish Government allocates resources for schools within Scotland with the way in which the Westminster Government allocates resources for schools within England. In each territory, school grants are allocated on the basis of formulae that consider the characteristics of pupils and schools, but differ in the specific indicators that they use, and the weights attached to those indicators.

In a statistical sense, these formulae appear to assess the relative spending needs of the devolved territories and LAs in a reasonably similar way (Table 7). The results suggest that NI has the highest relative spending need for school education and is currently not dedicating the level of resource to school education that its relative needs imply it should; Wales has relatively high spending needs but is currently spending more than enough to compensate for this need; Scotland's spending needs are broadly in line with England's, and this is reflected in its spending.

TABLE 7

Summary of results

\begin{tabular}{lcrrr}
\hline & England & \multicolumn{1}{c}{ Scotland } & Wales & NI \\
\hline Spending needs estimate per person & (England = 1): & & & \\
A: English FSS & 1.000 & 0.975 & 1.023 & 1.187 \\
B: Scottish GAE & 1.000 & 0.99 & 1.038 & 1.196 \\
C: 2015/16 English FSF & 1.000 & 1.067 & 0.994 & 1.223 \\
\hline G: Current spending per person & 1.000 & 0.997 & 1.092 & 1.111 \\
(England = 1) & & & & \\
\hline
\end{tabular}

It could be argued however that statistical similarity is not the same as political similarity. Varying Scotland's per pupil need relative to England's by $1 \%$ could equate to a $f 50 \mathrm{~m}$ difference in the grant allocation to Scotland (based on 600,000 Scottish pupils and per pupil spending in England of around 
$£ 8,500$ ). Whilst only representing $0.35 \%$ of its total budget, such a sum could be quite symbolic in the context of the politics of devolved funding; $f 50 \mathrm{~m}$ is roughly what the Scottish Government spends to mitigate the impacts of the Westminster Government's 'bedroom tax', and only slightly below the estimated cost of retaining the free prescription policy.

The analysis in this paper focuses on resource allocation for school funding for those aged 5-16. A needs-based replacement for the Barnett Formula would also need to consider how to assess education spending needs more widely, covering spending needs for pre-school education, and Further and Higher Education. In these areas however there is much greater policy divergence between the DGs, the clearest example of which relates to university tuition fees (university tuition remains free to Scottish students; in England tuition fees of up to $£ 9,000$ per year are payable; in Wales and $\mathrm{NI}$, tuition fees are subsidised to an extent for students from Wales and $\mathrm{NI}$ by the respective governments). Designing a system of needs assessment when policies diverge is potentially more challenging, as it is less clear how to define the relevant policy standard against which needs are assessed (King and Eiser, 2014). However, this is no more of an issue for needs assessment than it is for the existing Barnett Formula, which effectively takes English policy as the spending standard.

The conclusion of this paper is that there is greater similarity in how England and Scotland assess education spending needs than is sometimes assumed. This adds to previous literature which suggests that the countries' approaches to assessing health spending needs are also similar. However it remains unclear whether the further revenue decentralisation that is happening to Scotland, NI and Wales will strengthen calls to replace Barnett or reduce them. On the one hand, the Barnett derived block grant will become a diminishingly smaller component of the budgets of the DGs. On the other hand, retention of the Barnett Formula might be seen as incompatible with the greater fiscal autonomy of the DGs. Indeed, reform of Barnett might be seen as necessary either as part of a quid pro quo for further revenue decentralisation (in Scotland), or as a necessary reform to prevent the emergence of substantial disparities in the relative spending power of the DGs (in the case of Wales). 


\section{Acknowledgements}

This research has been funded through ESRC Research Grant RES-062-23-2814, 'Development of needs-based funding models for the devolved territories in the UK'. The grant ran from March 2011 - February 2013.

We are indebted to the editor of the journal and an anonymous referee for insightful comments on an earlier version of this paper; the responsibility for any remaining errors is our own.

\section{References}

All Party Parliamentary Taxation Group (2013) Achieving Autonomy: What the independence referendum means for Scotland's fiscal future. House of Commons, London

Bain, G. (2006) Strategic Review of Education. Department of Education Northern Ireland, Belfast.

Ball R., Eiser D. and King D. (2015) Assessing relative spending needs of devolved government: the case of healthcare spending in the UK, Regional Studies 49, 323-336.

Ball R., King D. and Eiser D. (2012a) Applying the Education FSS to the UK territories: method paper, University of Stirling Working Paper.

Ball R., King D. and Eiser D. (2012b) Applying the Scottish education GAE to the UK territories: method paper, University of Stirling Working Paper.

Blöchliger H. and King D. (2006) Less than you thought: the Fiscal Autonomy of Subcentral Governments, OECD Economic Studies 43, 155-88.

Bosch N. (2009) The reform of regional government finances in Spain, in Institut D'Economia de Barcelona (Ed) World report on fiscal federalism, pp. 58. Institut d'Economia de Barcelona, Barcelona.

Bramley G., Watkins D. and Karley N. K. (2011) An outcome-based resource allocation model for local education services in Wales, Environment and Planning C: Government and Policy 29, 848-71.

Cabinet Office (2015) Scotland in the United Kingdom: an enduring settlement. Stationary Office, London.

Cameron, D. (2012) Devolved school management review. Scottish Government, Edinburgh.

Chowdry, H., Muriel, A. and Sibieta, L. (2008) Level playing field? The implications of school funding. CfBT Education Trust, Reading. 
Chowdry H. and Sibieta L. (2011) School funding reform: an empirical analysis of options for a national funding formula, IFS Briefing Note BN123.

Christie A. and Swales J. K. (2010) The Barnett allocation mechanism: formula plus influence?, Regional Studies 44, 761-75.

Commission on devolution in Wales (2012) Empowerment and responsibility: financial powers to strengthen Wales. Commission on devolution in Wales, Cardiff.

Commonwealth Grants Commission (2010) Report of GST revenue sharing relativities - 2010 review. Commonwealth of Australia, Canberra.

Dearden L. and Vignoles A. (2011) Schools, Markets and League Tables, Fiscal Studies 32, 179-86.

Department for Education (2010) The school funding settlement for 2011-12: The pupil premium and Dedicated Schools Grant. Department for Education, London.

Department for Education (2012) School funding reform: next steps towards a fairer system. Department for Education, London.

Department of Education Northern Ireland (2013) Common Funding Scheme 2014/15. Department of Education Northern Ireland, Belfast

Fazekas M. (2012) School Funding Formulas: Review of main characteristics and impacts. OECD Education Working Paper No. 74. OECD, Paris.

Gibbons S., Machin S. and Silva O. (2012) Valuing school quality using boundary discontinuities, Journal of Urban Economics.

Glennerster H. (2002) United kingdom education 1997-2001, Oxford Review of Economic Policy 18, 120-36.

Hanushek E. A. (2010) Education production functions: developed country evidence, International Encyclopedia of Education 2, 407-11.

Hills J. (2010) An Anatomy of Economic Inequality in the UK-Report of the National Equality Panel, LSE STICERD Research Paper No.CASEREPORT60.

HM Treasury (2010) Funding the Scottish Parliament, Welsh Assembly Government, and Northern Ireland Assembly: statement of funding policy. HM Treasury, London.

Holmlund H., McNally S. and Viarengo M. (2010) Does money matter for schools?, Economics of education review 29, 1154-64.

House of Commons Select Committee on Education and Skills (2003) Seventh Report, Session 2002-3. Stationary Office, London. 
Independent Commission on Funding and Finance for Wales (2010) Fairness and accountability: a new funding settlement for Wales. Welsh Government, Cardiff.

King, D. and Eiser, D. Reform of the Barnett Formula with needs assessment: can the challenges be overcome? Forthcoming, Regional Studies. http://www.tandfonline.com/doi/abs/10.1080/00343404.2014.933799?journalCode=cr es20\#.VS_PYvzF9YA

Lago-Peñas I., Lago-Peñas S. and Martinez-Vazquez J. (2011) Guest Editorial: The Political and Economic Consequences of Decentralization, Environment and Planning C: Government and Policy 29, 197-203.

Lecours A. and Béland D. (2010) Federalism and fiscal policy: The politics of equalization in Canada, Publius: The Journal of Federalism 40, 569-96.

Levačić R. (2006) Funding schools by formula, in N. C. Soguel and P.Jaccard (Eds) Governance and Performance of Education Systems, pp. 205-245. Springer, Dordrecht.

Local Government Association. (2013) Press Release, 2 July 2013: Ten point plan to revive England's economy and public services

Machin S., McNally S. and Meghir C. (2010) Resources and standards in urban schools, Journal of human capital 4, 365-93.

Machin S., McNally S. and Wyness G. (2012) Education across the UK Nations: Performance, Inequality and Evidence. Program on Education Policy and Governance Working Papers Series. PEPG 12-08., Program on Education Policy and Governance, Harvard University.

Mackay R. and Williams J. (2005) Thinking about need: public spending on the regions, Regional Studies 39, 815-28.

McLean, I., Lodge, G. and Schmuecker, K. (2008) Fair Shares: Barnett and the Politics of Public Expenditure. IPPR, London.

McLean I. and McMillan A. (2005) The distribution of public expenditure across the UK regions, Fiscal Studies 24, 45-71.

Midwinter A. (2002) Territorial resource allocation in the UK: a rejoinder on needs assessment, Regional Studies 36, 563-77.

National Audit Office (2011) Landscape Review: Formula Funding of Local Public Services. Audit Office, .

ODPM (2005) The local government finance report (England) 2005/6 - consolidated version following amending report. The Stationary Office, London. 
Scottish Government (2008) Green Book for Grant Aided Expenditure 2008-11. Scottish Government, Edinburgh.

Select Committee on the Barnett Formula (2009) The Barnett Formula. The Stationary Office, London.

The Smith Commission (2014) Report of the Smith Commission for further devolution of powers to the Scottish Parliament. The Smith Commission, Edinburgh

Smith, P. (2006) Formula funding of public services. Routledge, Abingdon.

Welsh Government (2012) Welsh Local Government Revenue Settlement 2012-13:

Background information for Standard Spending Assessments. Welsh Government, Cardiff.

West A. (2009) Redistribution and Financing Schools in England under Labour Are Resources Going Where Needs Are Greatest?, Educational Management Administration \& Leadership 37, 158-79. 